Journal of Southeast Asian

Volume 10

Issue 1 Volume 10 (2015)

Article 6

2015

\title{
Mother's Song
}

Tony Innouvong

Tony Innouvong, tinnouvong@gmail.com

Follow this and additional works at: https://docs.lib.purdue.edu/jsaaea

Part of the Poetry Commons

\section{Recommended Citation}

Innouvong, Tony (2015) "Mother's Song," Journal of Southeast Asian American Education and Advancement: Vol. 10 : Iss. 1, Article 6.

DOI: $10.7771 / 2153-8999.1126$

Available at: https://docs.lib.purdue.edu/jsaaea/vol10/iss1/6

This document has been made available through Purdue e-Pubs, a service of the Purdue University Libraries. Please contact epubs@purdue.edu for additional information.

This is an Open Access journal. This means that it uses a funding model that does not charge readers or their institutions for access. Readers may freely read, download, copy, distribute, print, search, or link to the full texts of articles. This journal is covered under the CC BY-NC-ND license. 


\section{ISAAEA Journal of Southeast Asían American Education and Advancement}

Volume $10(2015)$

WWW.JSAAEA.org

Mother's Song

by

Tony Innouvong

\section{Mother's Song}

My mother was a soldier who escaped the drought

Conquered Southeast Asia's Namkhong

With banana leaves and a warrant on her head

Phaya Nak under her feet

Bloodied hands for freedom

Machete in one hand

Legacy in the other

Two refugee camps later

Her lungs can rest a little

Nongkhai is now a photo

Nostalgia that shall never be relived

She's got a new home now

Made of gold

Home is what I call her when she's draped in gold

Fingers sun kissed they warm when she waves

She's only cold when reminded that her new home doesn't belong to her

This land is hard on her feet

But still she must move

Till soil for her seeds.

\footnotetext{
(c)

SDRERIGHISRESERVEDReaders are free to copy, display, and distribute this article, as long as the work is attributed to the author(s) and the Journal of Southeast Asian American Education \& Advancement, it is distributed for non-commercial purposes only, and no alteration or transformation is made in the work. More details of this Creative Commons license are available at http://creativecommons.org/licenses/by-nc-nd/3.0/. All other uses must be approved by the author(s) or JSAAEA.

Journal of Southeast Asian American Education \& Advancement, Vol. 10 (2015) ISSN: 2153-8999
} 


\section{About the Author}

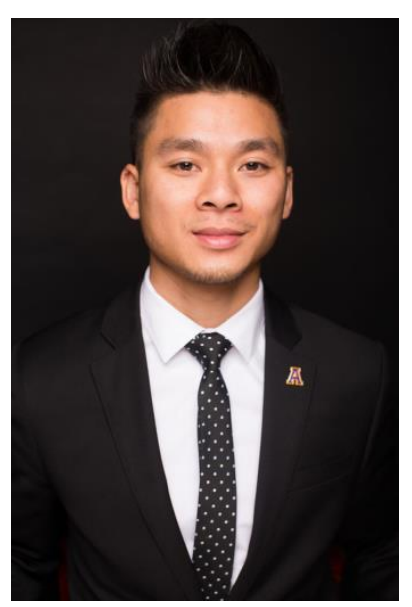

Tony Innouvong is a Seattle-born, first generation Lao American. Fueled by his love for the arts, he founded Freshest Roots in 2009, a community arts organization focused on creating opportunities for young people to cultivate their passions in the arts. Under the alias, Illaphant, he released three musical projects and performed throughout the US. He received his undergraduate degree in international business from Seattle University and graduate degree in business administration from Alcorn State University. Currently, Tony is working on a menswear line that fuses traditional Lao culture with modern fashion. 


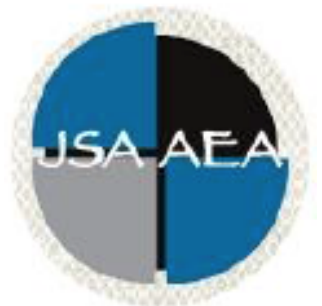

Volume 10 (2015)

\title{
Journal of Southeast Asian American
}

\section{Education and Advancement}

\author{
www.JSAAEA.org
}

\section{Editor}

Dr. Wayne E. Wright

Purdue University

\section{Associate Editors}

Dr. Chhany Sak-Humphry

University of Hawaii at Manoa

Dr. Phitsamay Sychitkokhong Uy

University of Massachusetts, Lowell

\section{Book Review Editor}

Dr. Vichet Chhuon

University of Minnesota

\section{Creative Works Editor \\ Bryan Thao Worra \\ Lao Assistance Center}

\section{Journal Manager}

Marshall Klassen

Purdue University

\section{Editorial Review Board}

Dr. Steve Arounsack

California State University, Stanislaus

Dr. Sovicheth Boun

The State University of New York at Fredonia

Dr. George Chigas

University of Massachusetts, Lowell

Dr. Hien Duc Do

San Jose State University

Dr. Sophal Ear

Occidental College

Dr. Jeremy Hein

University of Wisconsin, Eau Claire

Dr. Nancy H. Hornberger

University of Pennsylvania

Dr. Peter Nien-Chu Kiang

University of Massachusetts, Boston
Dr. Carl L. Bankston III

Tulane University

Dr. Phala Chea

Lowell Public Schools

Dr. Loan Dao

University of Massachusetts, Boston

Dr. Changming Duan

University of Missouri, Kansas City

Dr. Sothy Eng

Lehigh University

Dr. Vincent K. Her

University of Wisconsin, Eau Claire

Dr. Peter Tan Keo

New York University

Dr. Kevin K. Kumashiro

University of San Francisco 


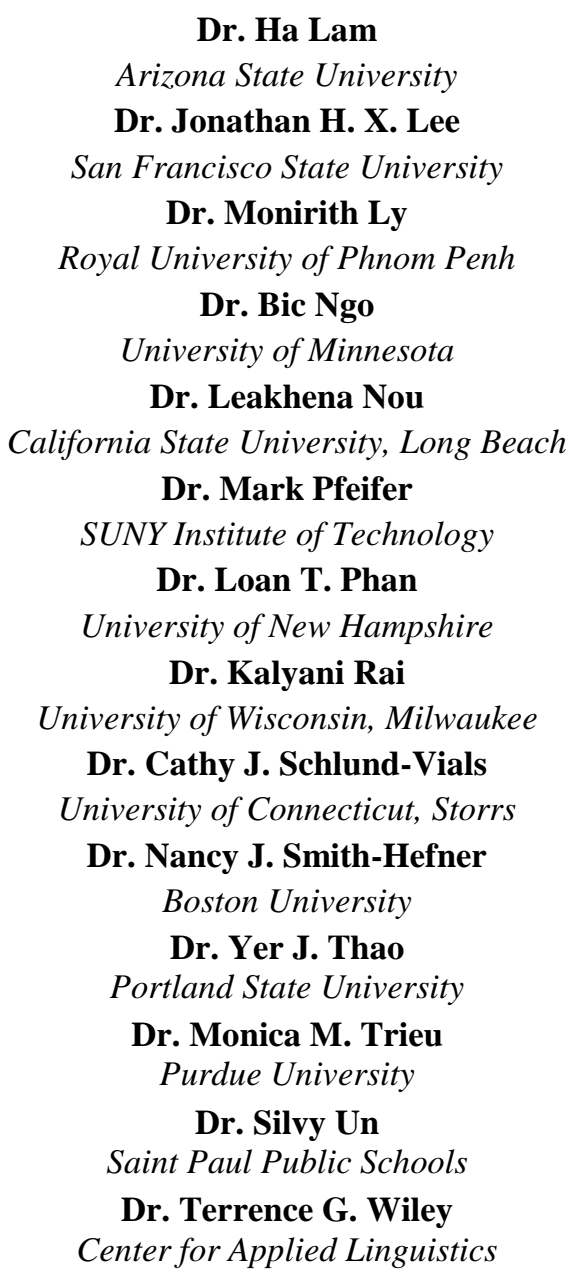

Dr. Ha Lam

Arizona State University

Dr. Jonathan H. X. Lee

San Francisco State University

Dr. Monirith Ly

Royal University of Phnom Penh

Dr. Bic Ngo

University of Minnesota

Dr. Leakhena Nou

California State University, Long Beach

Dr. Mark Pfeifer

SUNY Institute of Technology

Dr. Loan T. Phan

University of New Hampshire

Dr. Kalyani Rai

University of Wisconsin, Milwaukee

Dr. Cathy J. Schlund-Vials

University of Connecticut, Storrs

Dr. Nancy J. Smith-Hefner

Boston University

Dr. Yer J. Thao

Portland State University

Dr. Monica M. Trieu

Purdue University

Dr. Silvy Un

Saint Paul Public Schools

Dr. Terrence G. Wiley

Center for Applied Linguistics

Dr. Ravy Lao

California State University, Los Angeles

Dr. Stacey Lee

University of Wisconsin, Madison

Dr. Sue Needham

California State University, Dominguez Hills

Dr. Max Niedzwiecki

Daylight Consulting Group

Dr. Clara Park

California State University, Northridge

Dr. Giang Pham

University of Massachusetts

Dr. Karen Quintiliani

California State University, Long Beach

Dr. Angela Reyes

Hunter College, The City University of New York

Dr. Fay Shin

California State University, Long Beach

Dr. Christine Su

Ohio University

Dr. Alisia Tran

Arizona State University

Dr. Khatharya Um

University of California, Berkeley

Dr. Linda Trinh Vo

University of California, Irvine

Dr. Yang Sao Xiong

University of Wisconsin-Madison

Dr. Zha Blong Xiong

University of Minnesota

\section{Doctoral Student Editorial Review Board}

\author{
Virak Chan \\ University of Texas at San Antonio \\ Annie BichLoan Duong \\ San Joaquin County Office of Education \\ Hoa Nha Nguyen \\ Boston College \\ Malaphone Phommasa \\ Marshall University \\ Molly Wiebie \\ The University of Texas at Austin
}

\author{
Keo Chea-Young \\ University of Pennsylvania \\ Dung Minh Mao \\ University of Minnesota \\ Thien-Huong Ninh \\ University of Southern California \\ Krissyvan Truong \\ Claremont Graduate University \\ Soua Xiong \\ San Diego State University \& \\ Claremont Graduate University
}

Anna H. Yang

University of Georgia 